\title{
An Analysis of Students' Vocabulary Ability in Finding Verb Through Song Lyrics in SMP Marisi Medan
}

\author{
${ }^{1}$ Mian Ronauli Manurung, ${ }^{2}$ Irvi Marca A. Munte, ${ }^{3}$ Khairun Nisa, \& ${ }^{4}$ Sri Ninta Tarigan \\ 1234 Univeristy of Prima Indonesia \\ 1email : mianronaulimanurung6@gmail.com \\ 2 email : irvimunte98@gmail.com \\ 3 email : khairunnissa2212@gmail.com \\ ${ }^{4}$ email : srinintatarigan@unprimdn.ac.id
}

\begin{abstract}
This study is to find out the students' vocabulary ability in finding verb through song lyrics. And this study has done in SMP MARISI Medan. Speaking is one of the language skills in English. That's why mastery vocabulary is needed by every people. Vocabulary is a set of similar words within a person's language. A vocabulary, usually developed with age, serves as as useful and fundamental tool for communication and acquiring knowledge. Teaching vocabulary through song is not only sing or reading lyric of song and fun so that is make the students passive but also process of teaching these vocabulary to be applied in activities in a form of communication. The result of analysis showed that finding verb through song lyrics answered by students'. The students' who got excellent is $18(60 \%)$, the students' who got good is $10(33,3 \%)$. so after the writer got there are score, the writer concluded that students' who got excellent and good categorized able. The students' who got categorized Bad 2 (6,6\%) students'. So, after the writer got there are score, the writer conclude that students' who got enough and bad categorized unable in finding verb. The researcher hopes that the students' should be active in learning especially on vocabulary . because vocabulary is one of important skills in learning English. The students' must develop their vocabulary so they can speak well in English. Moreover, the students' may get more knowledge to improve their vocabulary in English.
\end{abstract}

Keywords: Song lyrics, Verb, Vocabulary

\section{INTRODUCTION}

Vocabulary is a list or collection of words or phrases usually alphabetically arranged and explained or defined. Vocabulary can be defined, rougly, as the words we teach in the foreign language (Penny, 1991: 60).Vocabulary is primarily associated with the number of words that a person knows; one either has a large or a small vocabulary. But the word has many shades of meaning and is nicely representative of the nuanced and multi- hued nature of so much of the English lexicon. The acquisition an educating get educative vocabulary is very important fo a successful second language without extensive vocabulary that won't be able to use structure and function. Of course, the agreed vocabulary for Junior High School curriculum. In teaching and learning vocabulary there are many Media; one of the media is song.

Song is an artistic form of expression based of sound, with distinct pithches, 
pattern and form, generally consider a complete work, whether musically or lyrically or song is composed by the art of tone or voicing sequence, combination, and the relation of temporal to produce a piece of music having unity continuity. Song is very useful for students to make students to make classroom more interest and can stimulate their brain.

According to Harmer "music is a powerful stimulus for the proper involvement of students, because it speaks directly to their emotions while still allowing the use of their brain to analyze it and the effect is very hopeful. It means song can stimulus students' brain and makes students happy in teaching learning process. That is why song is very useful for students because, with song teacher can stimulate student's brain to learning English move interesting so that the students will enjoy with English teaching process and will be serious to study English vocabulary. Teaching vocabulary through song is not only sing or reading lyric of song and fun so that is make the students passive but also process of teaching these vocabulary to be applied in activities in a form of communication.

The First, Based on the writers observation in Field Practice Experience ( Praktek Kerja Lapangan : PPL ) They found that students were attractive in English song. They were not know the meaning of the English song language . That's why the writers want to know how is English song use in English teaching technique to contribute the students vocabulary. The Second, the writers found that their vocabulary needed to add. When they talk in English they still use code mixing.
From the research background of the study, the writers formulates this research problems as follows:

1. How is the students' vocabulary ability through song lyrics finding verb?

2. What are the students' difficulties in vocabulary through song lyrics finding verb?

The problem of the study above, the purpose of this research are:

1. To discover how students' vocabulary abilities in finding verb through song lyrics.

2. To find out the students' difficulties in vocabulary finding verb through song lyrics.

Supported of the problems, the writers finality this research on the students' vocabulary ability in finding verb through song lyrics in SMP Marisi Medan at eight grade students.

\section{METHODS}

The types to explain the time and place of the study, subject of the study, instrument of data collection, data collection techniques and data analysis techiques. Qualitative research focuses on understanding social phenomena and providing rich verbal descriptions of settings, situations, and participants (Ary et all : 2010: 424).

The study was done at SMP Marisi Medan. It located at Guru Sinumba Medan. The writerschoosed this school because of this research had never conducted before in this school. The time that the writer used the research is in Thursday until Tuesday. 
The subject of this research was the eight grade students' of SMP Marisi Medan. With 32 students.

In this research, the writers used observation and test. The writers gave the test to knowing the students' ability in finding verb through song lyrics. After that the writers observed the students to know what the reason they have difficulties in finding verb through song lyrics.

The writers make some procedures, to collected the data:

First, the test given to the students.

Second, the explanation given by the writers to the students how to do the test,

Third, the writers control them and collect their answer

The data already collected and analyzing by using the procedures:

1. The writers collect the answer that the students already have done.

2. The writers make the score.

In making score of the students' answer, the writers used the formula:

Scoring the test :

$\mathrm{S}=\mathrm{CV} / \mathrm{I} \times 100 \%$

$\mathrm{S}=$ the score

$\mathrm{CV}=$ Correct Answer

$\mathrm{I}=$ the number of items as follow :

In this case, the writers uses category

Tabel 1. Level Comprehension

No Score Levels of Comprehension

$180100 \quad$ Excellent

\begin{tabular}{lll}
2 & $60-79$ & Good \\
\hline 3 & $50-59$ & Enough
\end{tabular}

$4 \quad 0-49 \quad$ Bad

3. The writers evaluated and indentified the students' difficulties in vocabulary through song lyrics finding verb method

\section{FINDINGS AND DISCUSSION}

1. Data Observation

The observation well done on Thursday, $11^{\text {th }}$ February 2020. The data of this research that all of students' scores from the test in finding verb through song lyrics. All of the students are 30 as the subject in this research. When collecting the data, the researcher used the song lyrics as the instrument. The researcher give three song lyrics to the students. And the song lyrics that the researcher prepare to the students are One Call Away ( CharliePuth), I'm Gonna Lose You ( Meghan Trainor) and Perfect ( Ed Sheeran). By the song lyrics the students will finding the verb to know their ability in vocabulary.

\section{Data Analysis}

The subject of this study is eight grade in SMP Marisi Medan on Thursday, $11^{\text {th }}$ 2020. With 30 students. While the research, the researcher observe and analyze the students activity in learning vocabulary.

In this research the students finding verb through song lyrics, so the researcher know their ability in vocabulary. And the students find the verb and making the meaning of the verb.

There are 3 song lyrics that the researcher prepare to the students:

\footnotetext{
| ELT-Lectura: Studies and Perspectivesin English Language Teaching

Copyright@ 2020 Mian Ronauli Manurung, Irvi Marca A. Munte, Khairun Nisa, \& Sri Ninta Tarigan
} 
Picture 1. This is the song lyric of Charlie Puth (One Call Away)

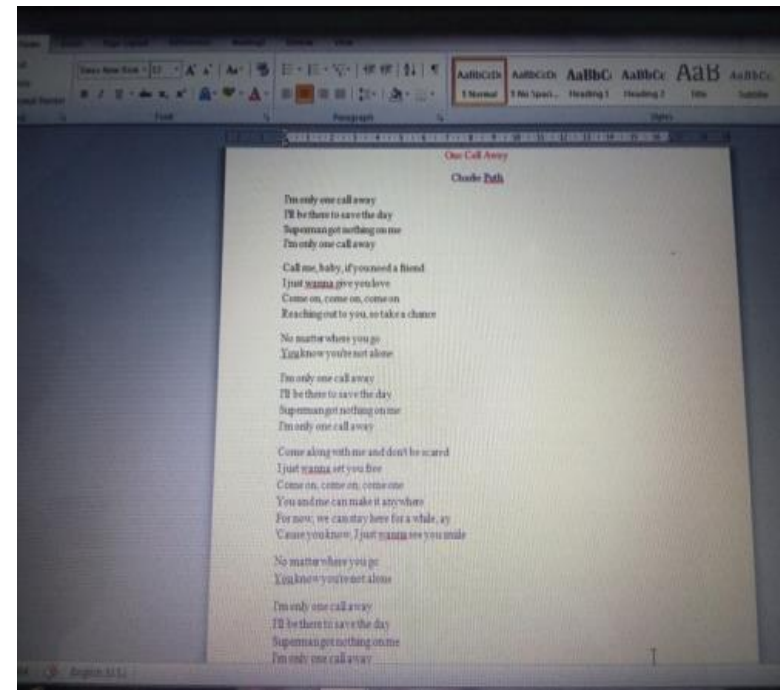

Picture 2. This is the song lyric of the

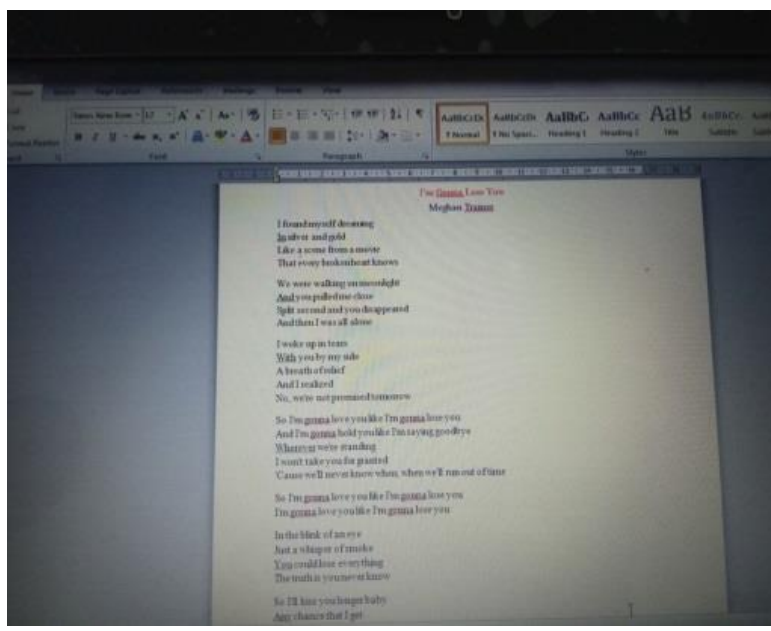
Meghan Trainor (I'm Gonna Lose You)

Picture 3. And the last is the song lyric of the Ed Sheeran ( Perfect)

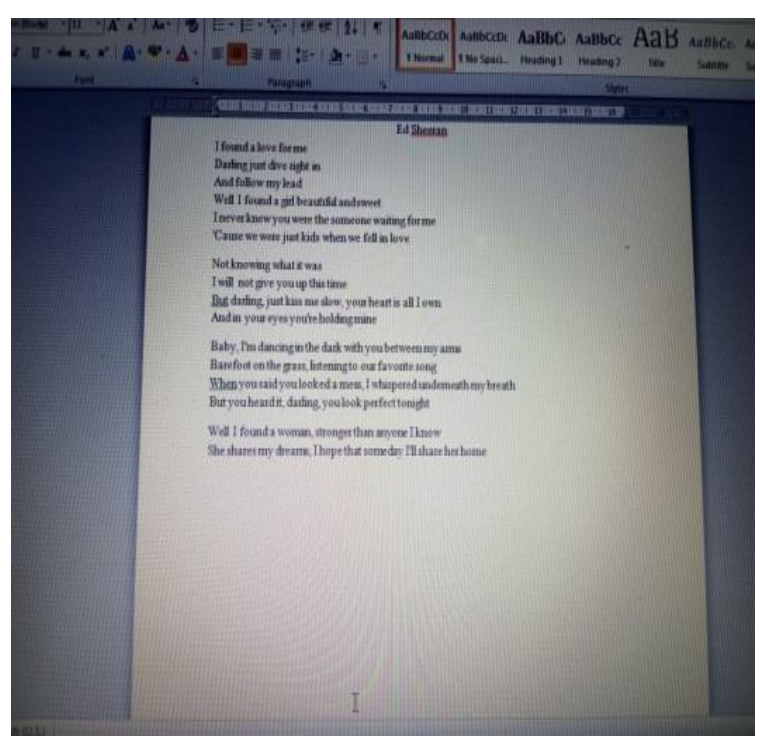

Maximum Score : 100

Minimum Score : 45

Score $: S=\frac{C V}{I} \times 100 \%$

$\mathrm{S}=$ the score

$\mathrm{CV}=$ Correct Answer

$\mathrm{I}=$ the number of items

Table 2. The Students' Score

No Name Correct Score

\begin{tabular}{clcc}
\hline 1 & Martinus Sihotang & 42 & 79 \\
\hline 2 & Anisa Voitah & 41 & 77 \\
\hline 3 & Rinto Ariah & 42 & 79 \\
\hline 4 & Say May & 44 & 83 \\
\hline 5 & Kristina Silaban & 44 & 83 \\
\hline 6 & $\begin{array}{l}\text { Maydina Arfani } \\
\text { Siregar }\end{array}$ & 44 & 83 \\
\hline 7 & Kristin Bulele & 46 & 86 \\
\hline
\end{tabular}

| ELT-Lectura: Studies and Perspectivesin English Language Teaching

Copyright@ 2020 Mian Ronauli Manurung, Irvi Marca A. Munte, Khairun Nisa, \& Sri Ninta Tarigan 


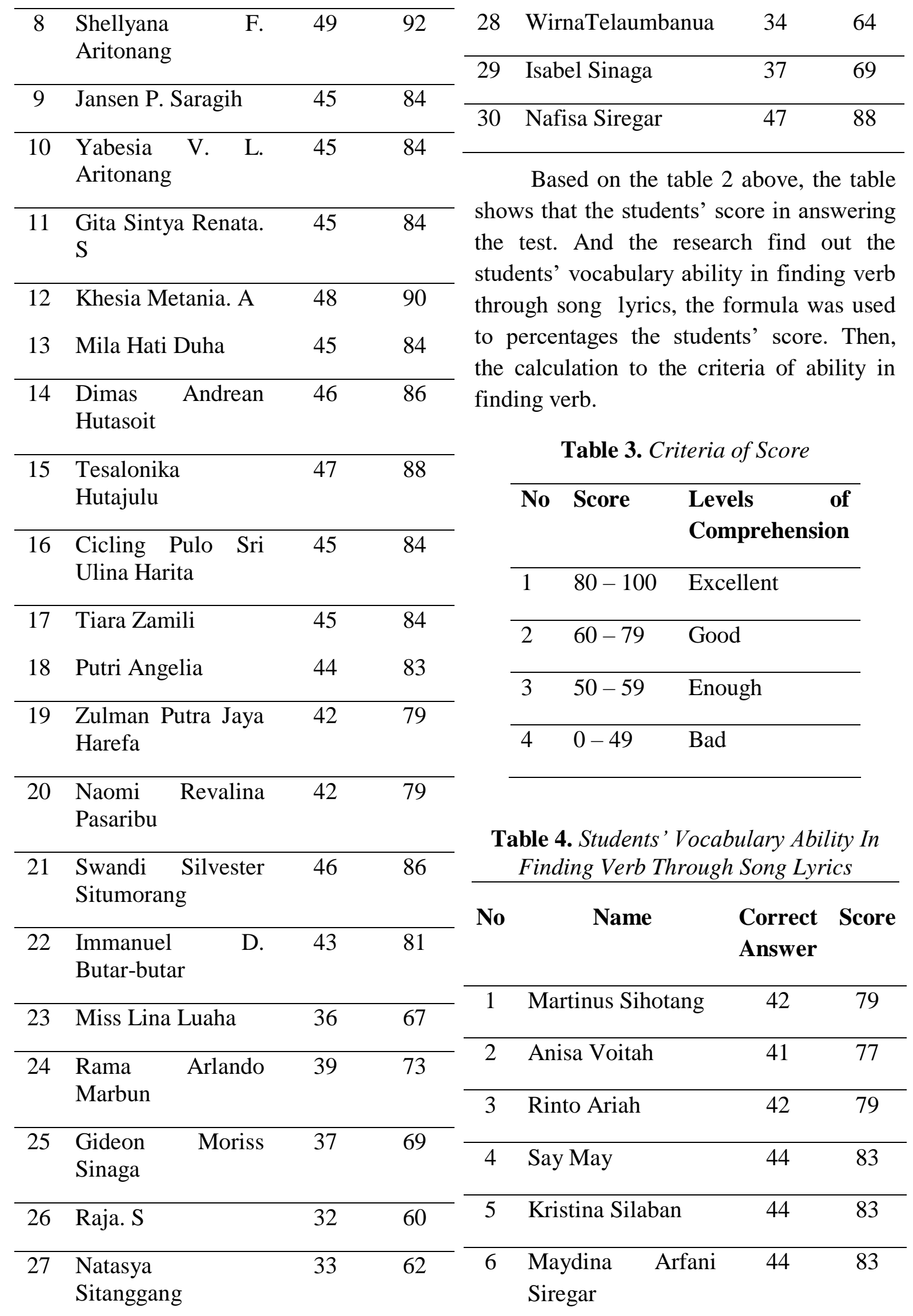

| ELT-Lectura: Studies and Perspectivesin English Language Teaching

Copyright@ 2020 Mian Ronauli Manurung, Irvi Marca A. Munte, Khairun Nisa, \& Sri Ninta Tarigan 


\begin{tabular}{|c|c|c|c|}
\hline 7 & Kristin Bulele & 46 & 86 \\
\hline 8 & $\begin{array}{ll}\text { Shellyana } & \text { F. } \\
\text { Aritonang } & \end{array}$ & 49 & 92 \\
\hline 9 & Jansen P. Saragih & 45 & 84 \\
\hline 10 & $\begin{array}{lll}\text { Yabesia } & \text { V. } & \text { L. } \\
\text { Aritonang } & & \end{array}$ & 45 & 84 \\
\hline 11 & $\begin{array}{l}\text { Gita Sintya Renata. } \\
\text { S }\end{array}$ & 45 & 84 \\
\hline 12 & Khesia Metania. A & 48 & 90 \\
\hline 13 & Mila Hati Duha & 45 & 84 \\
\hline 14 & $\begin{array}{ll}\text { Dimas Andrean } \\
\text { Hutasoit }\end{array}$ & 46 & 86 \\
\hline 15 & $\begin{array}{l}\text { Tesalonika } \\
\text { Hutajulu }\end{array}$ & 47 & 88 \\
\hline 16 & $\begin{array}{l}\text { Cicling Pulo Sri } \\
\text { Ulina Harita }\end{array}$ & 45 & 84 \\
\hline 17 & Tiara Zamili & 45 & 84 \\
\hline 18 & Putri Angelia & 44 & 83 \\
\hline 19 & $\begin{array}{l}\text { Zulman Putra Jaya } \\
\text { Harefa }\end{array}$ & 42 & 79 \\
\hline 20 & $\begin{array}{ll}\text { Naomi } & \text { Revalina } \\
\text { Pasaribu } & \end{array}$ & 42 & 79 \\
\hline 21 & Swandi Silvester S & 46 & 86 \\
\hline 22 & $\begin{array}{l}\text { Immanuel } \\
\text { Butar-butar }\end{array}$ & 43 & 81 \\
\hline 23 & Miss Lina Luaha & 36 & 67 \\
\hline 24 & $\begin{array}{l}\text { Rama } \\
\text { Marbun }\end{array}$ & 39 & 73 \\
\hline 25 & Gideon & 37 & 69 \\
\hline
\end{tabular}

Sinaga

\begin{tabular}{llcc}
\hline 26 & Raja. S & 32 & 60 \\
\hline 27 & $\begin{array}{l}\text { Natasya } \\
\text { Sitanggang }\end{array}$ & 33 & 62 \\
\hline 28 & WirnaTelaumbanua & 34 & 64 \\
\hline 29 & Isabel Sinaga & 37 & 69 \\
\hline 30 & Nafisa Siregar & 47 & 88
\end{tabular}

Based on the table 4 above, the students' comprehension in vocabulary should be shown in the table $\mathrm{N}$ is the number of items, $\mathrm{R}$ is the correct answer. The writer could explain that:

1. There were $18(60 \%)$ students' who were categorized Excellent.

2. There were $10(33,3 \%)$ students' who were categorized Good.

3. There were $2(6,6 \%)$ students' who were categorized Bad.

The result of analysis showed that finding verb through song lyrics answered by students' in finding verb through song lyrics.

1. The students' who got excellent is 18 $(60 \%)$, the students' who got good is 10 $(33,3 \%)$. So after the writer got there are score, the writer concluded that students' who got excellent and good categorized able. The students' who got categorized Bad $2(6,6 \%)$ students'. So, after the writer got there are score, the writer conclude that students' who got enough and bad categorized unable in finding verb.

From the result we know that the students have ability in vocabulary, so they have the highest score. And they

| ELT-Lectura: Studies and Perspectivesin English Language Teaching

Copyright@ 2020 Mian Ronauli Manurung, Irvi Marca A. Munte, Khairun Nisa, \& Sri Ninta Tarigan 
can know the verb through song lyrics that the researcher prepare to the students in SMP MARISI MEDAN. Consist the eight grade.

2. After analyzing the data, the researcher found the verb answered by students' at the school.

3. The difficulties of students in vocabulary is students are lazy to open a dictionary and lazy to memorize the difficult words. And now more time is used to play games.

\section{CONCLUSION}

The conclusion from the research and the data collection we know that : From finding verb through song lyrics, the highest percentage that the students' answered correctly. It becomes dominantly answered by the students' correctly. The students' who categorized Excellent is 18 $(60 \%)$ students', the students' categorized Good is $10(33,3 \%)$ students'. So, after the writer got there are score, the writer conclude that students' who got Excellent and Good categorized able. And the students' who got categorized Bad $2(6,6 \%)$ . So, after the writer got there are score, the writer got there are score, the writer conclude that students' who got Bad categorized unable in finding verb through song lyrics.

\section{REFERENCES}

Ary, et all. 2010. Introduction to Research in Education Wadsworth. Belmonth. USA.

Harmer, Jeremy. 2001. The Practice of English language Teaching Longman. Edinburg. England.

Alqahtani, Mofareh. 2015. The Importance of Vocabulary in Language Learning and Hoe to be taught. International Journal of Teaching and Education Vol. III, No. 3/2015.

Dawson, Catherine. 2002. Practical Research Method. How to books, ltd. London.

Hidayat, Nur. 2016. Improving Students' Vocabulary Achievement Through Song Journal of Educators Society.

Manik, Sondang and Chistiani, May. 2016. Teaching Vocabulary Using Matching Word on Computer Assisted, Language Learning International Journal of English Language Teaching Vol. 4 No.7.pp.1-26. August 2016

Masri, Amaal Al and Nazar, Majela Al. 2014.The Effect of Using Song

Arnold , Michael. (1995). The Language Style. London: Longman.

Penny, 1991: 60. The Meaning of Vocabulary 